1 The five Urochloa spp. used in development of tropical forage cultivars originate from

2 defined subpopulations with differentiated gene pools

3

4 J Higgins ${ }^{1}$, P Tomaszewska ${ }^{2}$, TK Pellny ${ }^{3}$, V Castiblanco $^{4}$, J Arango ${ }^{4}$, J Tohme ${ }^{4}, \mathrm{~T}$

5 Schwarzacher ${ }^{2}$, RA Mitchell ${ }^{3}$, JS Heslop-Harrison², JJ De Vega ${ }^{1}$

6

71 Earlham Institute, Norwich Research Park, Norwich NR4 7UZ, UK.

82 Department of Genetics and Genome Biology, University of Leicester, Leicester LE1 7RH,

9 UK.

103 Rothamsted Research, Harpenden, Hertfordshire AL5 2JQ, UK.

114 International Center for Tropical Agriculture (CIAT), 6713 Cali, Colombia.

13 HIGHLIGHT

14 We clarified the genetic make-up and population structure of 111 Urochloa spp. forage 15 grasses to inform cultivar development.

\title{
17 ABSTRACT
}

Background and Aims

Urochloa (syn. Brachiaria, and including some Panicum and Megathyrus) is a genus of tropical and subtropical grasses widely sown as forage to feed ruminants in the tropics. A better understanding of the diversity among Urochloa spp. allow us to leverage its varying ploidy levels and genome composition to accelerate its improvement, following the example from other crop genera.

Methods

We explored the genetic make-up and population structure in 111 accessions, which comprise the five Urochloa species used for the development of commercial cultivars. These accessions are conserved from wild materials from collection sites at their centre of origin in Africa. We used RNA-seq, averaging $40 \mathrm{M}$ reads per accession, to generate $1,167,542$ stringently 
selected SNP markers that tentatively encompassed the complete Urochloa gene pool used

30 in breeding.

31 Key Results

32 We identified ten subpopulations, which had no relation with geographical origin and represented ten independent gene pools, and two groups of admixed accessions. Our results support a division in $U$. decumbens by ploidy, with a diploid subpopulation closely related to $U$. ruziziensis, and a tetraploid subpopulation closely related to $U$. brizantha. We observed highly differentiated gene pools in $U$. brizantha, which were not related with origin or ploidy.

37 Particularly, one $U$. brizantha subpopulation clustered distant from the other $U$. brizantha and U. decumbens subpopulations, so likely containing unexplored alleles. We also identified a well-supported subpopulation containing both polyploid $U$. decumbens and $U$. brizantha accessions; this was the only group containing more than one species and tentatively constitutes an independent "mixed" gene pool for both species. We observed two gene pools

42 in U. humidicola. One subpopulation, "humidicola-2", was much less common but likely 43 includes the only known sexual accession in the species.

\section{Conclusions}

45 Our results offered a definitive picture of the available diversity in Urochloa to inform breeding and resolve questions raised by previous studies. It also allowed us identifying prospective

47 founders to enrich the breeding gene pool and to develop genotyping and genotype48 phenotype association mapping experiments.

50 Keywords: Brachiaria, grassland, breeding, forage, RNA-seq, population structure,

51 Poaceae 


\section{INTRODUCTION}

53 Urochloa (syn. Brachiaria, and including some Panicum and Megathyrus) is a genus of tropical 54 and subtropical grasses widely sown as forage to feed ruminants in the American and African 55 tropics, particularly in areas with marginal soils. Urochloa grasses exhibit good resilience and low nutritional needs (Miles, 2007, Gracindo et al., 2014, Maass et al., 2015). Five species, U. ruziziensis, U. decumbens, U. brizantha, U. humidicola, and U. maxima are broadly used as fodder plants, covering over 100M hectares in Brazil alone. Such an enormous area, about half that of each of the most widely grown cereals, wheat or maize, has a huge environmental impact in terms of displacement of native species, water usage, and provision of ecosystem services. In addition to extensive pasture systems in Latin America, Urochloa is also planted in intensive smallholder systems in Africa and Asia (Keller-Grein et al., 1996, Maass et al., 2015). Breeding programmes in different countries have exploited the diversity among Urochloa spp. for the development of commercial forage cultivars by recurrent selection over many years (Jank et al., 2014, Tsuruta et al., 2015, Worthington and Miles, 2015).

The genus Urochloa includes species previously classified under Brachiaria, Megathyrsus, Eriochloa and Panicum (Torres González and Morton, 2005, Kellogg, 2015). Joint missions between 1984 and 1985 conducted by the CGIAR (Consultative Group on International Agricultural Research) centres in several African countries collected wild materials from the species in the genus, mostly as live plant cuttings or ramets (Keller-Grein et al., 1996). These activities built a global grass collection with $\sim 700$ Urochloa accessions that are held at CIAT (Centro Internacional de Agricultura Tropical), ILRI (International Livestock Research Institute), and EMBRAPA (Brazilian Agricultural Research Corporation).

Three Urochloa species ( $U$. brizantha, $U$. decumbens, and U. ruziziensis) have been arranged in an agamic (apomictic) group or complex (Do Valle and Savidan, 1996, Renvoize et al., 1996, Ferreira et al., 2016, Triviño et al., 2017). Crosses between $\sim 10$ founders from these three species were completed in the late 1980s and their progeny constitutes the basis of the 
current recurrent selection breeding programmes at CIAT and EMBRAPA (Miles et al., 2006).

On the other hand, $U$. humidicola and $U$. dictyoneura have been arranged in the "humidicola complex" (Lutts et al., 1991, Renvoize et al., 1996, Triviño et al., 2017). More recently, independent $U$. humidicola breeding programs have also been established at CIAT and EMBRAPA after the discovery in the mid-2000s of a natural sexual polyploid germplasm accession that could be crossed with other apomictic polyploid $U$. humidicola pollen donors (Jungmann et al., 2010, Vigna et al., 2011a).

Urochloa spp. show varying ploidy levels and sub-genome compositions (Do Valle and Savidan, 1996, Keller-Grein et al., 1996, Tomaszewska et al., 2021b, Tomaszewska et al., 2021a), which likely result in a highly diverse gene pool that can be leveraged for continued improvement through breeding. Exploiting sub-genome variability among species and ploidy levels has been highly successful in the improvement of other crop tribes, such as Triticeae and Brassicaceae (Gale and Miller, 1987, Burton et al., 2004, Ali et al., 2016). However, genetic composition and relationships in Urochloa are poorly understood; studies from countries with active Urochloa breeding programmes have explored the phylogeny in these species to inform breeding, but projects leveraged of a limited number of markers, such as ITS, RAPD, SSR, ISSR, and microsatellites (Torres González and Morton, 2005, Jungmann et al., 2010, Vigna et al., 2011a, Vigna et al., 2011b, Ferreira et al., 2016, Triviño et al., 2017)

Urochloa spp. with apomictic or mixed reproduction have particularly resulted in odd levels of ploidy and contribute to increased intraspecific variability. Polyploidy has many benefits for plants, namely heterosis, gene redundancy, and loss of self-incompatibility and gain of asexual reproduction. In a recent work (Tomaszewska et al., 2021b), we used flow cytometry to determine the ploidy of over 350 Urochloa accessions from these collections and propose an evolutionary model. This work extended and corrected some previous studies (Penteado et al., 2000, Mendes-Bonato et al., 2002). We also concluded ploidy was not related to geographical origin, which agrees with previous results (Jungmann et al., 2010, Vigna et al., 
2011a, Vigna et al., 2011b, Triviño et al., 2017). In another recent work (Worthington et al., 2021), we have made available a genome assembly and gene annotation of a diploid accession of $U$. ruziziensis (GCA_003016355), which has allowed a greater use of genomics to characterise these materials. For example, we identified loss-of-function (LOF) genes related to forage quality and environmental impact using allele mining (Hanley et al., 2020).

Here, we have characterised the genetic make-up and population structure of 111 accessions, which are representative of the collections of wild materials in Africa in 1984 and 1985. These 111 accessions belong to the five Urochloa spp. that are used in the development of commercial forage cultivars. We used RNA-seq from total RNA, so tentatively encompassing the complete Urochloa gene pool used in breeding to obtain a definitive picture of the available diversity, resolve questions raised by previous studies, and identify prospective founders to improve the breeding gene pool.

\section{METHODS}

\section{RNA extraction and sequencing}

We sequenced 111 accessions from five Urochloa (syn. Brachiaria) species. 104 accessions were sampled at the single time from the in-situ field collection maintained by the Genebank at the International Center for Tropical Agriculture (CIAT) in Cali, Colombia. Accessions sourced from CIAT are named as e.g. "CIAT 26146", but we have removed "CIAT" from our text. Fresh leaf material was collected and immediately frozen in liquid nitrogen. Samples were ground in liquid nitrogen and lyophilised. Total RNA was extracted as described in Hanley et al. (2020) with the difference that prior to DNAse treatment the pellets were dried in a rotary evaporator (Eppendorf, USA) and stored at room temperature. Another seven accessions were obtained from the United States Department of Agriculture (USDA, GA, USA) as seeds. These seven accessions include "PI" at the beginning of their ID. These seven accessions were sampled at a different time than the other accessions after growing in glasshouses at University of Leicester, UK. We generated one single sample from each accession, and we 
use "sample" and "accessions" as synonyms in our case through the text. For all samples, Illumina sequencing using standard RNA-seq library preparations with 150 bp paired reads was conducted by Novogene Europe (Cambridge, UK). The raw reads were deposited in SRA under Bioproject PRJNA513453.

\section{Read alignment and SNP calling}

Raw reads were pre-processed using Trim galore v. 0.5 (Krueger, 2015) with the options for Illumina paired reads and trimming $13 \mathrm{bps}$ at the $5^{\prime}$ end in both reads. Processed reads were aligned to the available Urochloa genome (Worthington et al., 2021), which corresponded to a U. ruziziensis accession. RNA to DNA alignments were done using STAR v. 2.6.0c (Dobin et al., 2013) with a minimum overlap of $30 \%$ and a maximum mismatch of 3 bp per alignment, in order to allow for mapping from more distant species to the genome. Alignment coverage was calculated using BEDTools genomecov. SNP calling was done using GATK v. 3.7.0 and the recommended pipeline for RNA-seq (Van der Auwera et al., 2013). Firstly, we used PicardTools v. 2.1.1 to annotated duplicate reads using the option MarkDuplicates. Later, we used GATK's tool SplitNCigarReads with the options “-rf ReassignOneMappingQuality -RMQF 255 -RMQT 60 -U ALLOW_N_CIGAR_READS" to reformat some alignments that span introns to match conventions for the final step. The final step was SNP calling using GATK's tool HaplotypeCaller with all the samples at the same time (multisample mode). SNP calling was run with the options "-ploidy 6 -dontUseSoftClippedBases -stand_call_conf 20 maxNumHaplotypesInPopulation 128" to obtain a good quality calling from RNA alignments. GATK identified 6,461,493 variants, which included 5,757,116 SNPs. These were filtered for a minimal allele frequency (MAF) of $1 \%$ to give a set of $4,722,195$ SNPs. Sites with a depth of lower than 5 were set to missing, then sites with more than $40 \%$ missing data were removed to give a final set of $1,167,542$ SNPs. Two additional subsets were obtained by filtering out either the 67 samples $(895,667$ SNPs) in the agamic group or the $U$. humidicola samples (512,611 SNPs). These subsets were filtered for MAF of $1 \%$. 


\section{Population analysis}

Population structure analysis was performed through ADMIXTURE (Alexander and Lange, 2011) using $K=3$ to $K=10$ for the 111 samples, $K=2$ to $K=8$ for the 67 samples and $K=2$ to $K=8$ for the 28 samples. Each value of $K$ was run 10 times, the cross-validation error was averaged over the 10 runs. The 10 output files were combined using CLUMPP within the R package POPHELPER v.2.2.7 (Francis, 2017). The PCA (principal component analysis) was carried out using Tassel v5.2.41 (Bradbury et al., 2007).

\section{RESULTS}

Sequencing, aligning and SNP calling in a panel of Urochloa accessions from five species

We sequenced 111 accessions from five Urochloa (syn. Brachiaria) species: U. ruziziensis, Species identity and ploidy were previously determined using plant architecture traits and flow cytometry of fluorescently stained nuclei (Tomaszewska et al., 2021a, Tomaszewska et al., 2021b). The country of origin of 92 accessions was known and for 75 accessions we also knew the collection coordinates (Fig. 1). Accessions were collected in a broad range of latitudes (20.08S to $11.37 \mathrm{~N}$ ) but not of longitudes (26.98E to $42.05 \mathrm{E}$ ), except for one $U$. brizantha accession from Cameroon. Annotations were summarised in Table 1 and detailed in Suppl. Table 1.

Samples were aligned to the available Urochloa genome assembly and annotation (Worthington et al., 2021), which corresponds to a diploid U. ruziziensis sample. Two welldefined groups of species were observed based on aligning metrics (Fig. 2); over $70 \%$ of the reads from $U$. ruziziensis, $U$. decumbens and $U$. brizantha (all but one) accessions had more than $70 \%$ of reads that aligned in the reference genome once (uniquely-mapping reads). On the contrary, accessions from U. maxima and U. humidicola showed a percentage of uniquely- 
mapping reads under $70 \%$ (Fig. 2A). The grouping was correlated to the genetic distance to the reference genome (reference bias).

The percentage of reads mapping in multiple loci (multi-mapping reads) increased with ploidy (Fig. 2B) for the group of the accessions belonging to the species $U$. ruziziensis, $U$. decumbens and $U$. brizantha; diploids had a percentage of multi-mapping reads under $5 \%$, while it was over $5 \%$ in most polyploid accessions. However, the percentage of multi-mapping reads in the other species, which are more distant species to the reference, was directly proportional to the total number of mapped reads (Fig. 2B), i.e. independent of ploidy.

RNA-seq reads covered 268.84 Mbps ( $36.7 \%$ of the 732.5 Mbps genome assembly). The covered regions are more than 2.5 times the original gene annotation from the $U$. ruziziensis genome (43,152 genes comprising $102 \mathrm{Mbps})$. The median read coverage was 25 reads in the covered regions, and the average read coverage in these regions was $2587 \pm 54293$ reads. After SNP calling and filtering, the average SNP density in the genome was 7.3 SNPs/Kbp, or $17.9 \mathrm{SNPs} / \mathrm{Kbp}$ if only considering the read covered part of the genome. Using the 43,152 genes and 202,681 exons annotated in the genome reference, the median was 69 and 13 SNPs in each gene and exon (average was 95 and 36 per gene and exon, respectively). 34,981 of the annotated genes had at least one SNP.

\section{Admixture analysis}

We employed genetic admixture analysis for defining subpopulations. To assign 111 Urochloa accessions to subpopulations, the admixture (Fig. 3) and principal component (Fig. 4) analysis were considered together. The "admixture model" assumes that each individual has ancestry from one or more of "K" genetically distinct sources. An estimation of four subpopulations $(K=4)$ was selected based on the CV error (Suppl. Fig. 1A) and population structure (Fig. 4). A minimum threshold of $50 \%$ genetic composition was used to assign accessions to groups. This allowed us to place the accessions in four groups (Fig. 3): U. humidicola (28 accessions), 
U. maxima (13 accessions), "agamic group 1" (54 accessions from the three remaining species) and a closely related "agamic group 2" (that corresponded with the "brizantha-1" subpopulation). Three samples obtained from USDA and identified simply as "Urochloa sp." showed an admixture of these four groups and were annotated as "admixed". Accession 26438 (sample 86) was received as U. humidicola. Since it clustered with the U. maxima accessions, we reassigned it into that species. When we reduced the number of groups $(\mathrm{K}=$ 3 ), the $U$. humidicola and $U$. maxima species clustered together, but the agamic groups 1 and 2 were consistent (Suppl. Figure 2). When we increased the number of groups ( $K=5)$, a new group split from the "agamic group 1" (that corresponded with the "brizantha-2" subpopulation). The twenty-eight accessions in the $U$. humidicola group had a basic chromosome number of 9 and high ploidy levels ranging from 6 to 9 . The twelve accessions in the U. maxima group had a basic chromosome number of 8 and are tetraploid. The 67 accessions in the agamic groups had a basic chromosome number of 9 and ploidy levels ranging from 2 to 6 (Tomaszewska et al., 2021b).

The admixture analysis was subsequently carried out using only the 67 accessions in the agamic group (Fig. 3B). An estimation of six groups $(K=6)$ was selected based on the CV error (Suppl. Fig. 1B) and population structure (Fig. 4). A minimum threshold of $70 \%$ shared genetic composition was used to assign accessions to each of the six groups. As shown in fig. 3B, the group "ruziziensis" was composed of all eleven $U$. ruziziensis accessions. It included one accession wrongly classified as $U$. decumbens. Within it, five samples showed shared ancestry (1-25\%) with diploid U. decumbens. All seven diploid U. decumbens accessions composed the group "decumbens-P2" and were pure accessions with no shared ancestry with any other group. Similarly, ten tetraploid $U$. decumbens formed the group "decumbens-P4" with pure accessions with no shared ancestry with any other group. However, another six tetraploid $U$. decumbens composed a different group together with five U. brizantha accessions, which was called "decumbens/brizantha". This group of eleven accessions was the only one composed by more than one species. Despite this mix, these 
accessions showed clear shared ancestry among them and no shared ancestry with any other group (except two samples with minor components). Finally, the group "brizantha-1" and "brizantha-2" were formed by eight and thirteen U. brizantha accessions, respectively. The group "brizantha-2" has pure accessions with no shared ancestry with other groups (with one minor exception under $5 \%$ ); while most samples in "brizantha-1" have shared ancestry with "decumbens-P4". The group "brizantha-1" corresponds to the previous "agamic group 2". The "brizantha-2" subpopulation was only observed in Ethiopia, while "brizantha-1" was observed in a broad range of latitudes. When we reduced the number of groups $(K=5)$, the "brizanthadecumbens" merged with the "decumbens-P4". When we increased the number of groups (K = 7), five "brizantha-1" split into an independent subpopulation (Suppl. Fig. 3).

The admixture analysis was finally completed using only the twenty-eight $U$. humidicola accessions (Fig. 3C). An estimation of two groups $(K=2)$ was selected based on the CV error (Suppl. Fig. 1C) and population structure (Fig. 4). A minimum threshold of $70 \%$ shared genetic composition was used to assign accessions to a group. The twenty-eight samples into the two groups: 23 accessions into "humidicola-1" and four accessions into "humidicola-2". Accession 16878 was an equal mixed from both $U$. humidicola groups and annotated as "humidicolaadmixed". When we increased the number of groups $(K=3$ and $K=4)$, we obtained a small subpopulation with the accessions with higher admixture (16878 and 26155) and an artificial split with some "humidicola-1" accessions in an additional group (Suppl. Fig. 4).

A smaller number of thirteen $U$. maxima accessions showed little genetic diversity compared to the other species. Because of the low diversity, we assigned all the $U$. maxima to a single subpopulation, named "maxima".

\section{Population structure by principal component analysis}

A principal component analysis (PCA) showed the relationship between the 111 accessions, species and admixture groups (Fig. 4A and 4C). The PCA was also done for the 67 accessions 
in the agamic group alone (Fig. 4B and 4D). The PCA analysis allowed us to define 12 clusters in total, which easily corresponded with the 10 subpopulations and two admixed groups. The distribution of accessions into subpopulations according to the species and ploidy annotations is represented in figure 5 .

All subpopulations contained accessions from a single species, except subpopulation "decumbens/brizantha". Remarkably, this subpopulation contained samples that showed greater similarity to each other -in spite of species- than to accessions from the same species in different subpopulations. The two diploid subpopulations, "decumbens-P2" and "ruziziensis" clustered together and apart from polyploid subpopulations. Subpopulation "brizantha-1" was more distant to other agamic subpopulations than "brizantha-2" despite accessions in "brizantha-1" showed shared admixture with tetraploid $U$. decumbens, while accessions in "brizantha-2" did not.

Two groups of accessions contained hybrids, one containing hybrids between the distant Urochloa species ("admixed" subpopulation) and another contained hybrids within the three species in the agamic group ("agamic-admixed"), which readily interbreed in control conditions.

\section{DISCUSSION}

We clarified the relationship between the gene pools from five Urochloa spp. that are used in the development of commercial forage cultivars. By using RNA-seq, we leveraged in an unprecedented number of markers, over 1.1M SNPs, that virtually encompassed the complete transcriptome from the accessions based on the total genome length covered by the reads ( $269 \mathrm{Mbp}$ or $37 \%$ of the genome). We obtained a median of 69 and 13 SNP sites per gene and exon, respectively, which makes this dataset a valuable resource for breeders and researchers (e.g. to design screening markers). The greater length compared to the annotated gene models (Worthington et al., 2021) was probably because the later only used 
bioRxiv preprint doi: https://doi org/10.1101/2021.07.21453213; this version posted July 22, 2021. The copyright holder for this preprint (which was not certified by peer review) is the author/funder, who has granted bioRxiv a license to display the preprint in perpetuity. It is made available under aCC-BY 4.0 International license.

304

transcriptomic data from $U$. ruziziensis. However compared with our dataset, that transcriptomic data was from multiple tissues and included stress conditions. The genus Urochloa includes species previously classified under other taxonomic groups. We have opted to annotate all as Urochloa supported by recent work (Tomaszewska et al., 2021b). E.g., we did observed the same distance between $U$. maxima and the agamic group than between $U$. humidicola and the agamic group.

We observed two subpopulations of $U$. brizantha, two subpopulations of $U$. decumbens, and one subpopulation with accessions from both $U$. brizantha and $U$. decumbens. The two $U$. decumbens subpopulations were divided by ploidy. Diploid $U$. decumbens clustered with $U$. ruziziensis, while tetraploid $U$. decumbens clustered with $U$. brizantha. This split in two $U$. decumbens subpopulations by ploidy was previously reported using microsatellites (Triviño et al., 2017). In previous studies, the relation of $U$. decumbens with the other two species has been discussed, as it was alternatively found closely related to $U$. ruziensis (Ferreira et al., 2016) or U. brizantha (Ambiel et al., 2008). In fact, both observations were correct depending on the ploidy of the accessions under consideration.

Based on our results, $U$. brizantha diversity is complex and divided in several gene pools. A group of eleven $U$. brizantha accessions was different enough to the rest of the agamic group to form an independent cluster ("agamic group 2"; Fig. 3A and 4A). This group of eleven accessions later formed the subpopulation "brizantha-1". Despite of "brizantha-1" being distant, we observed admixture between "brizantha-1" and "decumbens-P4", "brizantha-2" and "decumbens/brizantha" subpopulations (Fig. 3B). Among the possible evolutive scenarios that would explain the multiple shared ancestry in "brizantha-1" despite being more distant, previous studies have proposed a single polyploidization event taking place to establish both the tetraploid U. brizantha and U. decumbens (Pessoa-Filho et al., 2017, Tomaszewska et al., 2021b). The "brizantha-1" subpopulation was observed in a broad range of latitudes (e.g. in Ethiopia and Zimbabwe), while "brizantha-2" was only observed in Ethiopia. 
333 We obtained a subpopulation, named "decumbens/brizantha", that included an almost equal

334 number of $U$. decumbens and $U$. brizantha accessions. This is the only subpopulation with more than one species, and most accessions did not show shared ancestry with the other subpopulations from either of these species (Fig. 3B). Furthermore, the PCA also showed "decumbens/brizantha" clustered independently to other groups (in the top right corner of Fig. 4D). Remarkably, the "decumbens/brizantha" merged with the "decumbens-P4" when we did the admixture analysis with less subpopulations $(K=5)$. At the same time, two accessions (16173 and PI226049) shared ancestry with "brizantha-2" and were situated between the subpopulations "decumbens/brizantha" and "brizantha-2" in the PCA (Fig. 4D). Consequently, we concluded "decumbens/brizantha" cannot be merged with either "decumbens-P4" or "brizantha-2", but on the contrary, evidence supported it is an independent subpopulation.

Vigna et al. (2011b) observed three clusters in $U$. brizantha after evaluating 172 accessions from EMBRAPA's collection (so resulting from the same field work in 1980s than our dataset) using 20 SSR markers. Eleven accessions are common between both studies, and our subpopulations "brizantha-1" and "brizantha-2" corresponded with clusters II and I, respectively (Vigna et al., 2011b). Notably, their cluster III appears to include additional "brizantha-1" and "brizantha-2" accessions (16122, 16480), so does not correspond with our "decumbens-brizantha" subpopulation. Triviño et al. (2017) did not discussed a division among U. brizantha accessions, but included a tree resulting from UPGMA clustering based on 39 microsatellites that would also support at least two gene pools in $U$. brizantha.

In the centre of the agamic group, we identified the "agamic-admixed" accessions (Fig. 4D). This cluster of accessions included hybrid accessions resulting from interspecific species within the agamic group, and should not be confused with the "admixed" accessions (Fig. 4C), which resulted from crosses between more distant Urochloa species. Our analysis supports that the "agamic-admixed" are either progeny from crosses between $U$. decumbens and either 
bioRxiv preprint doi: https://doi org/101101/2021.07.21453213; this version posted July 22, 2021. The copyright holder for this preprint (which was not certified by peer review) is the author/funder, who has granted bioRxiv a license to display the preprint in perpetuity. It is made available under aCC-BY 4.0 International license.

U. decumbens or $U$. brizantha (16505, PI210724, PI292187); or between U. ruziziensis and either $U$. decumbens or $U$. brizantha $(26175,16494,26110,1752)$.

U. maxima is also known as Panicum maximum or Megathyrsus maximus. All U. maxima accessions (including accession 26438, which was incorrectly annotated as $U$. humidicola) showed very limited diversity (Fig. 4) and were assigned to a single subpopulation ("maxima"). This could reflect lower diversity in the species, or be a consequence of original collection and sampling strategy, but it suggests there would be limited gains from including multiple accessions from our study in breeding programmes.

We observed two different subpopulations in U. humidicola, named "humidicola-1" and "humidicola-2", plus a single accession (16878) that was an equal mix from both subpopulations. In the initial admixture analysis with all the 111 accessions (Fig. 3A), the "humidicola-2" and "humidicola-admixed" accessions had shared ancestry to the "agamic group 1", while the "humidicola-1" did not. Triviño et al. (2017) also observed a large group of $U$. humidicola accessions including all but three of their accessions. These three distant $U$. humidicola accessions were 675,679 and 26146. Accession 679 is a "humidicola-2" subpopulation in our study. Remarkably, 26146 is the sexual $U$. humidicola accession that allowed the establishment of breeding programmes in mid-2000s, and combining the results from both studies supports that the sexual 26146 accession is likely a "humidicola-2" accession. We only had collection information for one "humidicola-2" accession, but it was close to a "humidicola-1" accession, so it is not likely a geographical division. Vigna et al. (2011a) analysed 26 U. humidicola accessions and used UPGMA clustering based on 38 microsatellites to divide $U$. humidicola in two branches in the resulting tree. All seven common accessions with our study were "humidicola-1" and appeared in the top branch of the tree. The bottom branch may be "humidicola-2", since it included the sexual accession 26146, one accession (26149) not sequenced in our dataset, and the progeny from their crossing. On the other hand, two studies from the same group (Jungmann et al., 2010, Vigna et al., 2011a) 
identified five clusters in $U$. humidicola accessions using $\sim 50$ SSR markers. While multiple accessions were common to both studies, we did not find correlation between our results and the five clusters; i.e. "humidicola-1" accessions were evenly divided among the multiple clusters. In a similar conclusion, when we increased the number of tentative $U$. humidicola subpopulations ( $K=3$ and $K=4$ ), we found the additional groups to be artificial splits from "humidicola-1" and not supported by the PCA.

\section{CONCLUSION}

We clarified the relationship between the gene pools from five Urochloa spp. that are used in the development of commercial forage cultivars in different countries. We identified ten subpopulations in total, which had no relation with geographical collection, and represent ten independent gene pools (excluding the two admixed subpopulations). Our results support the division in $U$. decumbens by ploidy, with a diploid subpopulation closely related to $U$. ruziziensis, and a tetraploid subpopulation closely related to $U$. brizantha. We observed clearly differentiated gene pools in $U$. brizantha, which were not related with origin or ploidy. One of these gene pools, named "brizantha-1", clustered relatively distant to the rest of the agamic accessions despite having significant shared ancestry with tetraploid $U$. decumbens. Among the possible evolutive scenarios to explain this observation, it would support a single polyploidization event taking place to establish both the tetraploid $U$. brizantha and $U$. decumbens. The "brizantha-1" gene pool should be further explored for prospective founders in the agamic group since $U$. brizantha is particularly tolerant to neotropic insects, which is one of the main traits under selection. We also identified a well-supported subpopulation containing both polyploid $U$. decumbens and $U$. brizantha accessions that likely constitutes a third independent gene pool for both species. We observed two gene pools in U. humidicola. One subpopulation, "humidicola-2", was significantly smaller but likely includes the only known sexual accession. We also observed one case of natural hybridization between both $U$. humidicola groups. Our results offer a definitive picture of the available diversity and resolve questions raised by previous studies. They provide an insight into the diversity available for 
improvement through crossing, and a platform to identify target genes for forage grass

417 improvement, also providing gene sequences to allow for genome editing (CRISPR/Cas9)

418 approaches. Furthermore, as performance data become available, the data could be further

419 leveraged for GWAS (Genome Wide Association Studies), genotyping array construction, and

420 development of genetic markers for selection in breeding programmes.

421

\section{AUTHOR CONTRIBUTIONS}

423 JJDV, RACM, JT, TS and JSHH conceived and managed the project. JH and JJDV completed 424 the bioinformatics analysis. PT analysed and provided ploidy level and accessions 425 information. TKP, VC and JA selected, validated and collected the samples. TKP carried out 426 RNA extraction. JH and JJDV wrote the manuscript with contributions from all the authors.

\section{ACKNOWLEDGEMENTS}

429 This work was supported under the RCUK-CIAT Newton-Caldas Initiative "Exploiting 430 biodiversity in Brachiaria and Panicum tropical forage grasses using genetics to improve 431 livelihoods and sustainability", with funding from UK's Official Development Assistance 432 Newton Fund awarded by UK Biotechnology and Biological Sciences Research Council 433 (BB/R022828/1). Additional funding for this study was received from the CGIAR Research 434 Programmes on Livestock; and Climate Change, Agriculture and Food Security (CCAFS). JH and JJDV received additional funding from the Biotechnology and Biology Sciences Research Council (BBSRC)'s Global Challenge Research Fund (Project BB/P028098/1) and core strategic funding (Project BBS/E/T/000PR9818).

We are grateful to CIAT's Genebank and USDA's Germplasm Resources Information Network (GRIN) for their generous provision of germplasm. Germplasm held in the CIAT and USDA collections is available on request.

\section{DATA AVAILABILITY}

443 All the raw reads were deposited in SRA under Bioproject PRJNA513453. 


\section{CONFLICT OF INTEREST}

446 The authors declare no conflict of interest.

\section{REFERENCES}

Alexander DH, Lange K. 2011. Enhancements to the ADMIXTURE algorithm for individual ancestry estimation. BMC Bioinformatics, 12: 246.

Ali N, Heslop-Harrison JP, Ahmad H, Graybosch RA, Hein GL, Schwarzacher T. 2016. Introgression of chromosome segments from multiple alien species in wheat breeding lines with wheat streak mosaic virus resistance. Heredity, 117: 114-123.

Ambiel AC, Guaberto LM, Vanderlei TM, Machado Neto NB. 2008. Agrupamento de acessos e cultivares de três espécies de Brachiaria por RAPD. Acta Scientiarum. Agronomy, 30: 457-464.

\section{Bradbury PJ, Zhang Z, Kroon DE, Casstevens TM, Ramdoss Y, Buckler ES. 2007.} TASSEL: software for association mapping of complex traits in diverse samples. Bioinformatics, 23: 2633-5.

Burton W, Ripley V, Potts D, Salisbury P. 2004. Assessment of genetic diversity in selected breeding lines and cultivars of canola quality Brassica juncea and their implications for canola breeding. Euphytica, 136: 181-192.

Do Valle Cd, Savidan Y. 1996. Genetics, cytogenetics, and reproductive biology of Brachiaria. Brachiaria: biology, agronomy, and improvement: 147-163.

Dobin A, Davis CA, Schlesinger F, Drenkow J, Zaleski C, Jha S, Batut P, Chaisson M, Gingeras TR. 2013. STAR: ultrafast universal RNA-seq aligner. Bioinformatics, 29: $15-21$.

Ferreira RC, Cançado LJ, do Valle CB, Chiari L, de Souza AP. 2016. Microsatellite loci for Urochloa decumbens (Stapf) R.D. Webster and cross-amplification in other Urochloa species. BMC Res Notes, 9: 152. 
Francis RM. 2017. pophelper: an R package and web app to analyse and

$$
\text { visualize population structure. Mol Ecol Resour, 17: 27-32. }
$$

Gale MD, Miller T. 1987. The introduction of alien genetic variation in wheat. Wheat breeding: Springer.

Gracindo CV, Louvandini H, Riet-Correa F, Barbosa-Ferreira M, Castro MB. 2014. Performance of sheep grazing in pastures of Brachiaria decumbens, Brachiaria brizantha, Panicum maximum, and Andropogon gayanus with different protodioscin concentrations. Trop Anim Health Prod, 46: 733-7.

Hanley S, Pellny T, de Vega J, Castiblanco V, Arango J, Eastmond P, Heslop-Harrison J, Mitchell R. 2020. Allele Mining in Diverse Accessions of $<$ em $>$ Urochloa $</$ em $>$ and Megathyrsus spp. Tropical Grasses to Improve Forage Quality and Reduce Environmental Impact. bioRxiv: 2020.12.09.418087.

Jank L, Barrios SC, do Valle CB, Simeão RM, Alves GF. 2014. The value of improved pastures to Brazilian beef production. Crop and Pasture Science, 65: 1132-1137.

Jungmann L, Vigna BB, Boldrini KR, Sousa AC, do Valle CB, Resende RM, Pagliarini MS, Zucchi MI, de Souza AP. 2010. Genetic diversity and population structure analysis of the tropical pasture grass Brachiaria humidicola based on microsatellites, cytogenetics, morphological traits, and geographical origin. Genome, 53: 698-709.

Keller-Grein G, Maass B, Hanson J. 1996. Natural variation in Brachiaria and existing germplasm collections. Brachiaria: biology, agronomy, and improvement, 45: 16-42.

Kellogg EA. 2015. Flowering plants. Monocots: Poaceae: Springer.

Krueger F. 2015. Trim galore. A wrapper tool around Cutadapt and FastQC to consistently apply quality and adapter trimming to FastQ files, 516: 517.

Lutts S, Ndikumana J, Louant B. 1991. Fertility of Brachiaria ruziziensis in interspecific crosses with Brachiaria decumbens and Brachiaria brizantha: meiotic behaviour, pollen viability and seed set. Euphytica, 57: 267-274.

Maass BL, Midega CA, Mutimura M, Rahetlah VB, Salgado P, Kabirizi JM, Khan ZR, Ghimire SR, Rao IM. 2015. Homecoming of Brachiaria: Improved hybrids prove 
useful for African animal agriculture. East African Agricultural and Forestry Journal,

81: 71-78.

501

Mendes-Bonato AB, Junqueira Filho RG, Pagliarini MS, Do Valle CB, de Oliveira Penteado MI. 2002. Unusual cytological patterns of microsporogenesis in Brachiaria decumbens: abnormalities in spindle and defective cytokinesis causing precocious cellularization. Cell Biology International, 26: 641-646.

Miles JW. 2007. Apomixis for cultivar development in tropical forage grasses. Crop Science, 47: S-238-S-249.

Miles JW, Cardona C, Sotelo G. 2006. Recurrent selection in a synthetic brachiariagrass population improves resistance to three spittlebug species. Crop Science, 46: 10881093.

Penteado MdO, dos Santos A, Rodrigues IF, do Valle C, Seixas MAC, Esteves A. 2000. Determinação de ploidia e avaliação da quantidade de DNA total em diferentes espécies do gênero Brachiaria. Embrapa Gado de Corte-Boletim de Pesquisa e Desenvolvimento (INFOTECA-E).

Pessoa-Filho M, Martins AM, Ferreira ME. 2017. Molecular dating of phylogenetic divergence between Urochloa species based on complete chloroplast genomes. BMC Genomics, 18: 516.

Renvoize S, Clayton W, Kabuye C, Miles J, Maass B, Valle C. 1996. Brachiaria: biology, agronomy, and improvement. Morphology, Taxonomy, and Natural Distribution of Brachiaria (Trin.) Griseb: 1-15.

Tomaszewska P, Pellny TK, Hernández LM, Mitchell RAC, Castiblanco V, de Vega JJ, Schwarzacher T, Heslop-Harrison P. 2021a. Flow Cytometry-Based Determination of Ploidy from Dried Leaf Specimens in Genomically Complex Collections of the Tropical Forage Grass Urochloa s. I. Genes, 12: 957.

Tomaszewska P, Vorontsova MS, Renvoize SA, Ficinski SZ, Tohme J, Schwarzacher T, Castiblanco V, de Vega JJ, Mitchell RA, Heslop-Harrison P. 2021b. Complex polyploid and hybrid species in an apomictic and sexual tropical forage grass group: 
genomic composition and evolution in Urochloa (Brachiaria) species. bioRxiv, 2021.02.19.431966.

Torres González AM, Morton CM. 2005. Molecular and morphological phylogenetic analysis of Brachiaria and Urochloa (Poaceae). Mol Phylogenet Evol, 37: 36-44.

Triviño NJ, Perez JG, Recio ME, Ebina M, Yamanaka N, Tsuruta S-i, Ishitani M, Worthington M. 2017. Genetic Diversity and Population Structure of Brachiaria Species and Breeding Populations. Crop Science, 57: 2633-2644.

Worthington M, Perez JG, Mussurova S, Silva-Cordoba A, Castiblanco V, Cardoso

Tsuruta S-i, Shimoda K, Kouki K, Ebina M. 2015. The present status of C4 tropical grasses breeding and molecular approaches. Japan Agricultural Research Quarterly: $J A R Q$, 49: 203-215.

Van der Auwera GA, Carneiro MO, Hartl C, Poplin R, Del Angel G, Levy-Moonshine A, Jordan T, Shakir K, Roazen D, Thibault J, Banks E, Garimella KV, Altshuler D, Gabriel S, DePristo MA. 2013. From FastQ data to high confidence variant calls: the

Vigna BB, Alleoni GC, Jungmann L, do Valle CB, de Souza AP. 2011a. New Genome Analysis Toolkit best practices pipeline. Curr Protoc Bioinformatics, 43: 11.10.1-11.10.33.

Vigna BBZ, Jungmann L, Francisco PM, Zucchi MI, do Valle CB, de Souza AP. 2011b. Genetic diversity and population structure of the Brachiaria brizantha germplasm. Tropical Plant Biology, 4: 157-169.

Worthington M, Miles JW. 2015. Reciprocal full-sib recurrent selection and tools for accelerating genetic gain in apomictic Brachiaria. Molecular breeding of forage and turf: Springer. Arango JA, Jones C, Fernandez-Fuentes N, Skot L, Dyer S, Tohme J, Di Palma F, Arango J, Armstead I, De Vega JJ. 2021. A new genome allows the identification 
bioRxiv preprint doi: https://doi.org/10.1101/2021.07.21.453213; this version posted July 22, 2021. The copyright holder for this preprint

(which was not certified by peer review) is the author/funder, who has granted bioRxiv a license to display the preprint in perpetuity. It is made available under aCC-BY 4.0 International license. 
558 Table 1: Summary of the species (rows) and ploidy level (columns) of the 111 accessions

559 used in this study. Details about each accession were included in Suppl. Table 1.

\begin{tabular}{|r|c|c|c|c|c|c|c|c|}
\hline & $2 \mathrm{n}$ & $4 \mathrm{n}$ & $5 \mathrm{n}$ & $6 \mathrm{n}$ & $7 \mathrm{n}$ & $8 \mathrm{n} / 9 \mathrm{n}$ & $?$ & Total \\
\hline U. ruziziensis & 10 & & & & & & 1 & 11 \\
\hline U. decumbens & 8 & 17 & & & & & 1 & 26 \\
\hline U. brizantha & & 17 & 9 & 2 & & & 1 & 29 \\
\hline U. humidicola & & & & 10 & 16 & 2 & & 28 \\
\hline U. maxima & & 12 & & & & & $1^{*}$ & 13 \\
\hline U. spp. & & 2 & 1 & & & & 1 & $4^{\text {** }}$ \\
\hline
\end{tabular}

561 on the results. ${ }^{* *}$ Accession 1752 (U. spp.) clustered within the agamic group. 
bioRxiv preprint doi: $h$ ttps://doi. org/10.1101/2021.07 21.453213; this version posted July 22, 2021. The copyright holder for this preprint (which was not certified by peer review) is the author/funder, who has granted bioRxiv a license to display the preprint in perpetuity. It is made available under aCC-BY 4.0 International license.

563 Figure 1. Geographical origin of 92 accessions with collection coordinates (74 accessions) or 564 country of origin (18 accessions). Accessions were coloured by subpopulation. (A) Origin in

565 Sub-Sahara Africa. (B) Zoom into East Africa. (C) Zoom into the Great Lakes region.

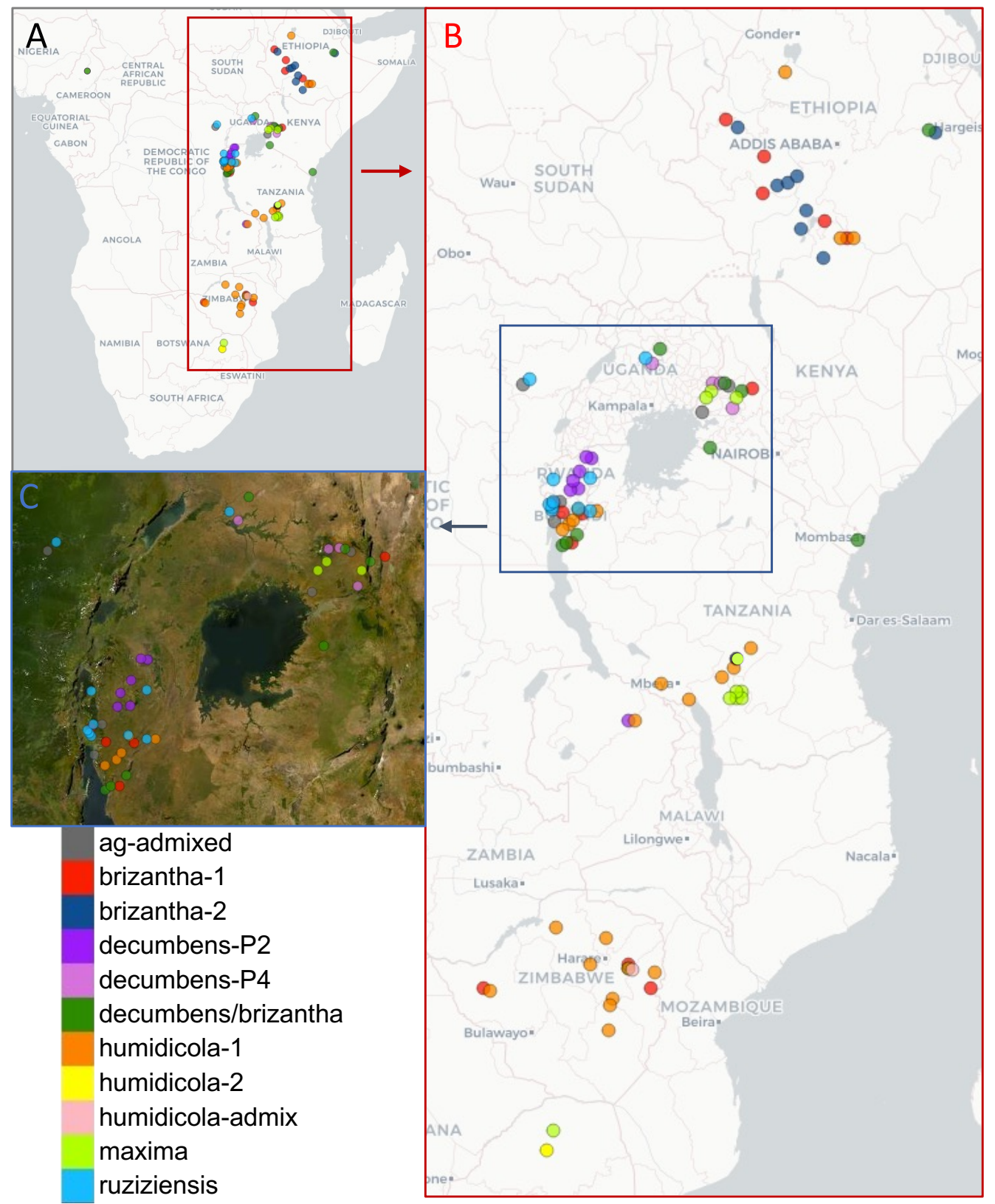


bioRxiv preprint doi: https://doi.org/10.1101/2021.07.21.453213; this version posted July 22, 2021. The copyright holder for this preprint (which was not certified by peer review) is the author/funder, who has granted bioRxiv a license to display the preprint in perpetuity. It is made available under aCC-BY 4.0 International license.

567 Figure 2. Percentage of reads aligning in either uniquely or in multiple positions in the genome.

568 The 111 accessions were coloured by species (A) or ploidy (B).

A

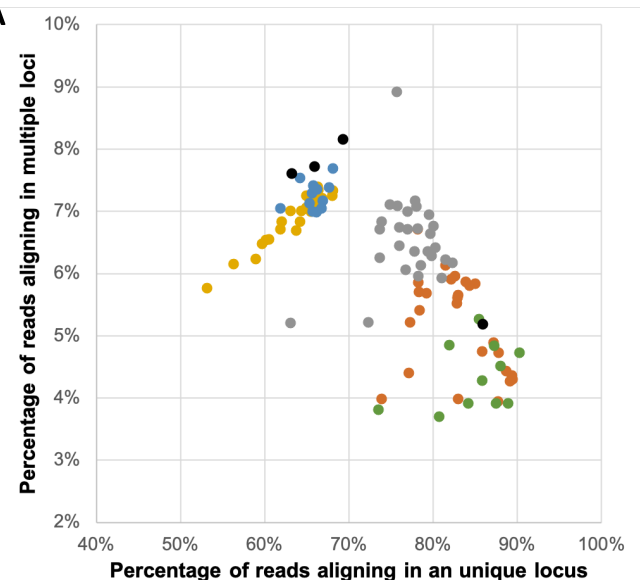

B

-U. decumbens - U. brizantha -U. humidicola -U. maxima U. ruziziensis

-U. spp.

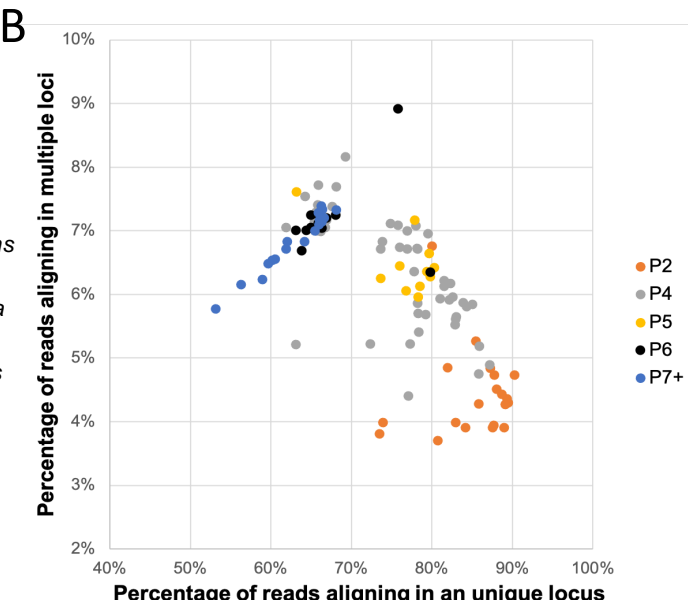


bioRxiv preprint doi: https://doi org/10.1101/2021.0721.453213. this version posted July 22 2021. The copvriaht holder for this preprint (which was not certified by peer review) is the author/funder, who has granted bioRxiv a license to display the preprint in perpetuity. It is made available under aCC-BY 4.0 International license.

570 Figure 3. Admixture analysis of the genetic ancestry inferred in the complete set of 111

571 accessions (A), the subset of 67 accessions in the agamic group (B), and the subset of $28 U$.

572 humidicola accessions (C). Ploidy level is included at the foot of each column. Each accession

573 is represented by a stack column partitioned by proportion of ancestral genetic component,

574 where each identified ancestral genetic component is represented with a different colour.

575 Accessions with a single colour are "pure". A minimum threshold of $50 \%$ (A) or $70 \%$ (B and

576 C) genetic composition was used to assign accessions to groups. In panel $C$, " $x$ " for

577 "humidicola-admix".
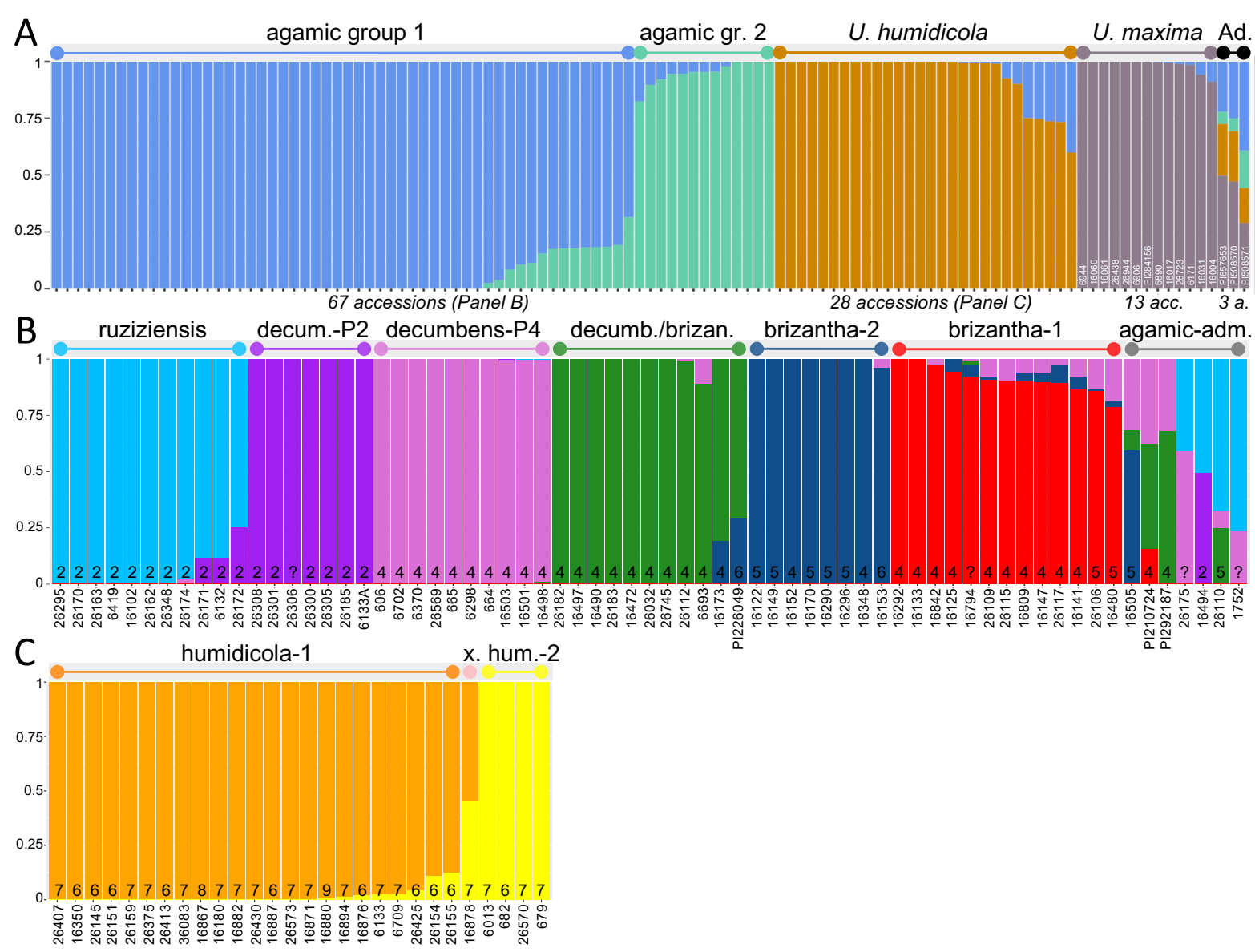
580 Figure 4. Population structure by Principal Component Analysis (PCA) using the top two 581 components to separate the complete set of 111 accessions ( $A$ and $C$ ) or the components 1 582 and 3 to separate the subset of 67 accessions in the agamic group (B and $D)$. Accessions 583 were coloured by species (A and $B)$ or subpopulation ( $C$ and $D)$.
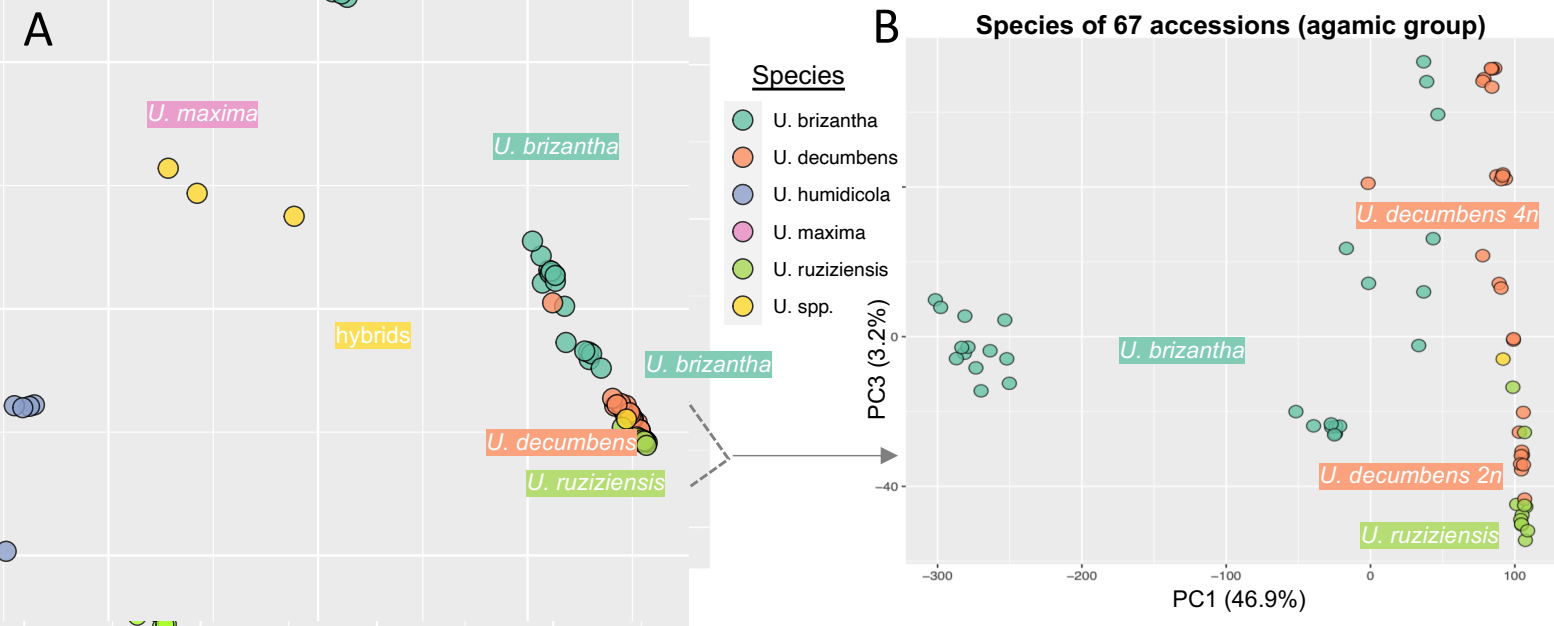

C Subpopulations of 111 accessions

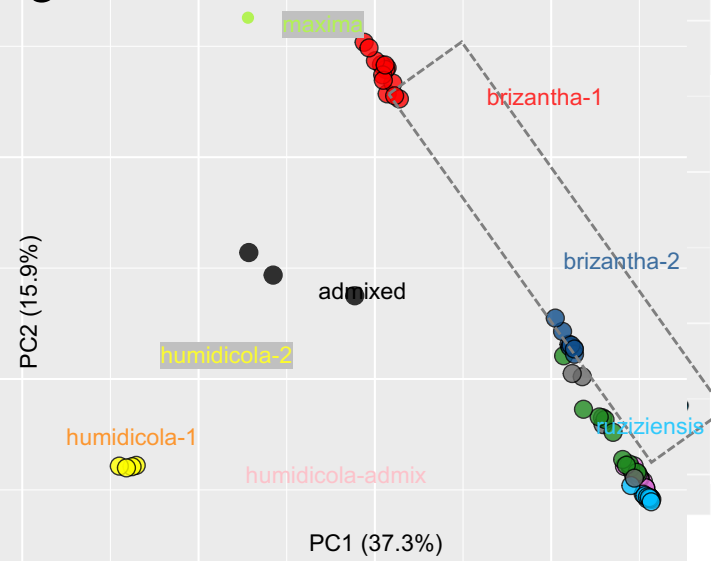

D Subpopulations of 67 accessions (agamic group)
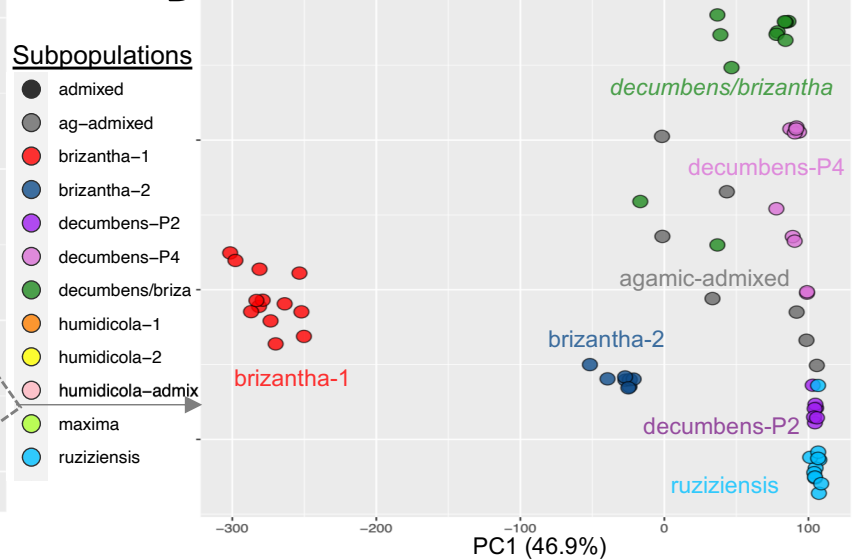
586 Figure 5: Distribution of accessions in subpopulations according to the species and ploidy

587 annotations. The number on each stream represents the number of accessions in that division.

588 Streams without a number represent a single accession.

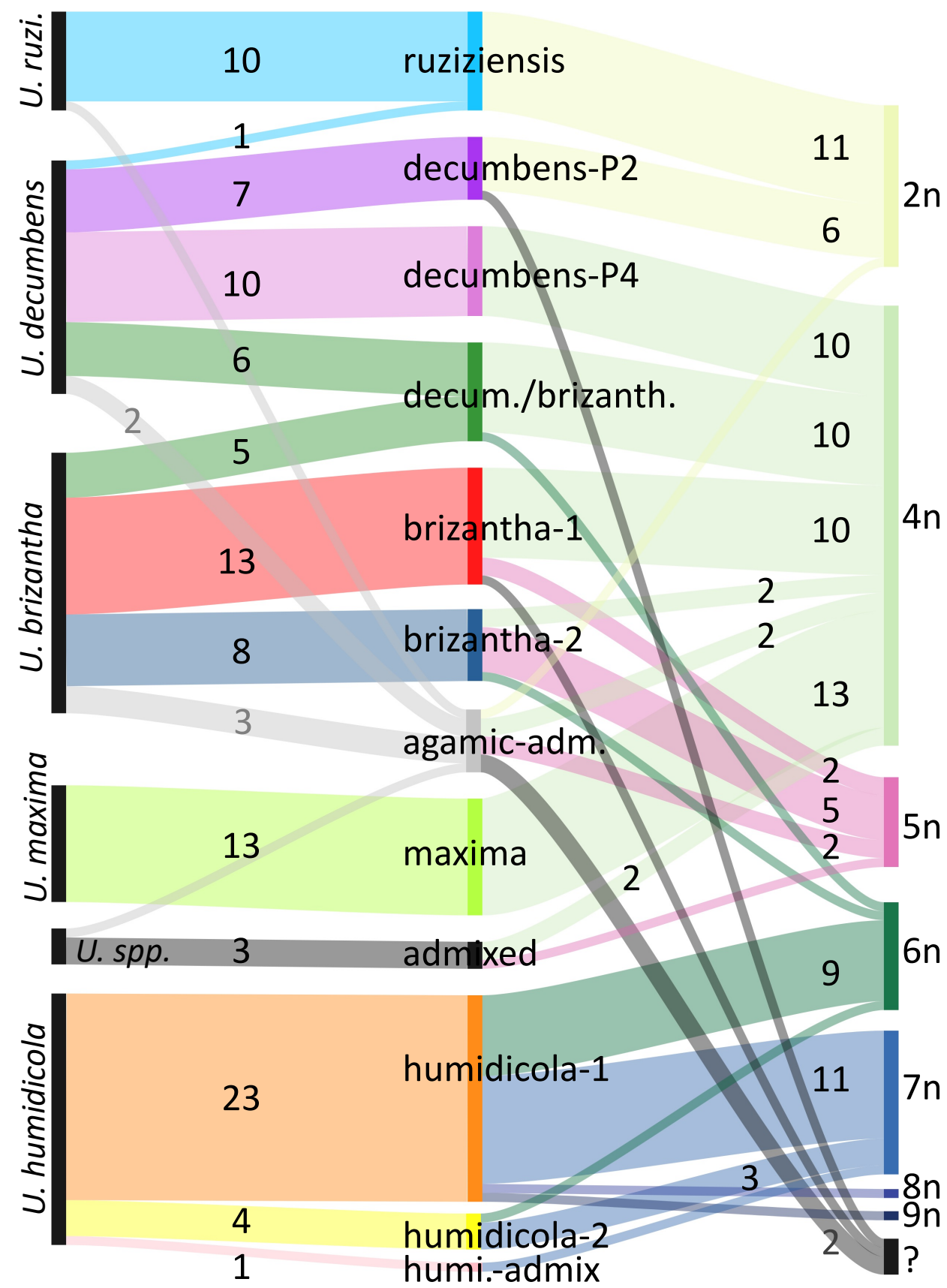


591 Supplementary Table 1. Sample number, accession number, species, ploidy, subpopulation, 592 architecture, collection location, and PCA position for each of the 111 accessions used in this 593 study.

594

595 Supplementary figure 1: Cross-validation (CV) error and chosen value for number of groups $596(\mathrm{~K})$ for the complete dataset of 111 accessions (A), the subset of 67 accessions in the agamic 597 group (B), and the subset of $28 U$. humidicola accessions (C). Cross-validation error is shown 598 on the Y-axis (vertical) and the number of hypothetical populations on the X-axis (horizontal). 599

600 Supplementary figure 2: Admixture analysis for alternative values for number of groups $(\mathrm{K}=$ 6013,4 -selected-, and 5) in the complete set of 111 accessions. Numbered by "sample id". 602

603 Supplementary figure 3: Admixture analysis for alternative values for number of groups $(\mathrm{K}=$ 6045,6 -selected-, and 7) in the subset of 67 accessions in the agamic group. Numbered by 605 "sample id".

606

607 Supplementary figure 4: Admixture analysis for alternative values for number of groups $(\mathrm{K}=$ 6082 -selected, 3 and 4) in the subset of 28 U. humidicola accessions. Numbered by "sample id". 